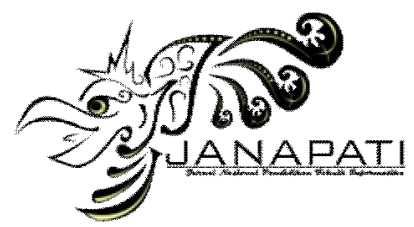

ISSN 2089-8673

Jurnal Nasional Pendidikan Teknik Informatika (JANAPATI)

Volume 1, Nomor 3, Desember 2012

\title{
Algoritma Enkripsi Citra Digital Berbasis Chaos dengan Penggabungan Teknik Permutasi dan Teknik Substitusi Menggunakan Arnold Cat Map dan Logistic Map
}

\author{
Oleh: Rinaldi Munir ${ }^{1}$ \\ Program Studi Informatika, Sekolah Teknik Elektro dan Informatika (STEI) \\ Institut Teknologi Bandung (ITB) \\ Jl. Ganesha 10, Bandung 40132 \\ E-mail: rinaldi-m@stei.itb.ac.id
}

\begin{abstract}
Abstrak
Di dalam makalah ini dipresentasikan sebuah usulan algoritma enkripsi citra digital yang menggabungkan teknik permutasi dan substitusi. Dua buah chaotic map digunakan untuk masingmasing teknik yaitu Arnold Cat Map dan Logistic Map. Sebelum dienkripsi, pixel-pixel di dalam citra diacak dengan Arnold Cat Map. Selanjutnya, pixel-pixel tersebut diubah nilainya melalui operasi $X O R$ dengan keystream yang dibangkitkan dari Logistic Map. Pixel-pixel dioperasikan seperti mode cipher block chaining. Hasil eksperimen pada citra grayscale dan citra berwarna menunjukkan cipher-image memiliki pixel-pixel yang terdistribusi uniform sehingga menyulitkan serangan dengan analisis statistik. Selain itu pixel-pixel yang berteatngga di dalam cipher-image memiliki koefisien korelasi yang rendah, yang mengindikasikan bahwa pixel-pixel tersebut sudah tidak memiliki hubungan linier (korelasi). Sifat sensitivitas pada chaos telah diperlihatkan yang mengindikasikan algoritma ini aman dari exhaustive-key search attack.
\end{abstract}

Kata kunci: enkripsi, citra, chaos, Arnold Cat Map, Logistic Map, permutasi, substitusi

\section{Pendahuluan}

Citra (image) atau gambar merupakan salah satu bentuk multimedia yang penting. Citra menyajikan informasi secara visual dan informasi yang disajikan oleh sebuah citra lebih kaya daripada yang disajikan secara tekstual. Citra digital tidak hanya disimpan di dalam storage seperti hard disk, flash disk, $C D, D V D$, dan perangkat memori lainnya, tetapi juga ditransmisikan melalui saluran publik seperti internet. Untuk citra yang bersifat privat atau yang bersifat rahasia, penyimpanan dan pengiriman citra perlu memperhatikan aspek keamanan. Citra yang bersifat privat misalnya foto dokumen pribadi yang hanya boleh dilihat oleh pemilik atau orang-orang yang diberi otoritas saja. Citra yang bersifat rahasia contohnya adalah citra hasil penginderaan jarak jauh (foto satelit) yang merekam potensi kekayaan alam sebuah negara.

Selain untuk citra privat dan rahasia, aspek keamanan merupakan fitur yang penting pada citra berbayar. Hanya pelanggan yang telah membayar saja yang dapat mengakses informasi di dalam citra. Sebuah video digital pada hakekatnya disusun oleh rangkaian frame citra diam yang ditampilkan dalam tempo yang sangat singkat. Untuk industri multimedia seperti Pay TV atau video on demand, perlindungan terhadap siaran video memainkan peranan yang penting, sebab siaran video dipancarkan secara broadcast melalui saluran transmisi (yang dapat disadap) tetapi hanya pelanggan yang membayar saja yang dapat menikmati siaran TV, sedangkan pelanggan ilegal tidak dapat mengakses siaran video tersebut.

Solusi terhadap keamanan citra digital dari pengakasesan yang ilegal adalah dengan mengenkripsinya. Tujuan enkripsi citra adalah menyandikan citra (plain-image) sehingga tidak dapat dikenali lagi (cipher-image). Saat ini enkripsi citra sudah telah digunakan secara luas sebagai salah satu teknik menjaga keamanan informasi. Enkripsi merupakan salah satu teknik keamanan pesan di dalam kriptografi, termasuk pesan dalam bentuk citra. Salah satu layanan yang diberikan 


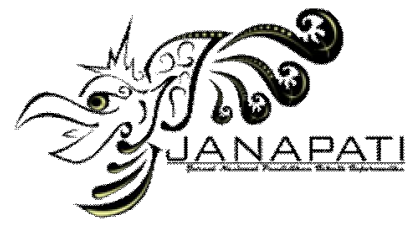

ISSN 2089-8673

Jurnal Nasional Pendidikan Teknik Informatika (JANAPATI)

Volume 1, Nomor 3, Desember 2012

oleh kriptografi adalah kerahasiaan pesan (confidentiality), dan confidentiality diimplementasikan dengan enkripsi dan dekripsi pesan (Schneier, 1996).

Para peneliti sudah banyak mengembangkan algoritma kriptografi untuk enkripsi, namun sebagian besar algoritma tersebut ditujukan untuk mengenkripsi pesan dalam bentuk teks. Meskipun algoritma enkripsi konvensional seperti DES, AES, Blowfish, Serpent, RC4, RSA, ElGamal, Rabin, dapat juga mengenkripsi citra, namun mereka tidak mangkus untuk diterapkan. Hal ini disebabkan citra mempunyai karakteristik yang berbeda dengan data tekstual. Sebuah citra umumnya memiliki kapasitas data yang sangat besar, sehingga enkripsi citra memerlukan volume komputasi yang besar. Beberapa aplikasi yang mempunyai kebutuhan real-time seperti teleconference, live video streaming, dan lain-lain, jelas memerlukan kecepatan komputasi yang sangat tinggi sehingga algoritma konvensional jelas tidak cocok untuk mengenkripsi citra.

Selain karena alasan volume, karakteristik citra yang membedakan dengan teks adalah korelasi data antar tetangga. Data di dalam teks hanya bertetangga dengan data sebelum (predecessor) dan sesudahnya (successor), sedangkan di dalam citra pixel-pixel-nya bertetangga dengan pixelpixel lain dalam delapan penjuru mata angin sehingga korelasinya dengan delapan pixel tetangganya tinggi. Oleh karena itu, setelah sebuah citra dienkripsi maka yang harus diperhatikan adalah pixel-pixel di dalam cipher-image seharusnya tidak memiliki korelasi dengan pixel-pixel tetangganya.

Karena alasan-alasan spesifik di atas, maka perlu dikembangkan algoritma yang khusus untuk citra digital. Penelitian tentang enkripsi citra dilakukan dengan intensif. Para peneliti telah banyak mengembangkan algoritma enkripsi citra digital. Menurut Younes (2008), kebanyakan algoritmaalgoritma enkripsi citra dapat dikelompokkan menjadi dua kelompok. Kelompok pertama adalah algoritma enkripsi selektif non-chaos, sedangkan kelompok kedua adalah algoritma enkripsi selektif atau non-selektif yang berbasis chaos. Yang dimaksud dengan algoritma selektif adalah algoritma yang mengenkripsi hanya sebagian elemen di dalam citra namun efeknya citra terenkripsi secara keseluruhan. Tujuan algoritma enkripsi selektif adalah mengurangi volume komputasi, yang konsekuensinya adalah menghemat waktu proses enkripsi. Enkripsi selektif cocok untuk aplikasi yang membutuhkan persyaratan real-time.

Kriptografi berbasis chaos menjadi topik penelitian yang atraktif saat ini. Chaos digunakan di dalam kriptografi karena tiga alasan: (1) sifat chaos yang sensitif terhadap kondisi awal sistem, (2) chaos berkelakuan acak, dan (3) nilai-nilai chaos tidak memiliki periode. Review beberapa algoritma enkripsi citra dengan menggunakan skema chaos dapat dibaca di dalam Sharma (2010).

Dua operasi dasar di dalam algoritma enkripsi citra adalah permutasi (atau transposisi) dan substitusi. Permutasi mengubah posisi pixel-pixel di dalam citra, sedangkan subsitutsi mengubah nilai pixel. Makalah ini menyajikan sebuah algoritma enkripsi citra berbasis chaos yang mengkombinasikan teknik permutasi dan substitusi. Dua buah fungsi chaos yang digunakan adalah Arnold Cat Map dan Logistic Map. Arnold Cat Map digunakan untuk mengacak susunan pixel-pixel, sedangkan Logistic Map digunakan sebagai pembangkit keystream yang kemudian dienkripsikan dengan pixel-pixel hasil permutasi. Pixel-pixel dienkripsikan dengan mode seperti mode $C B C$ pada block-cipher, meskipun yang dioperasikan tidak dalam bentuk blok-blok data melainkan pixel per pixel.

\section{Chaos}

Teori chaos sudah menajdi topik penelitian yang atraktif di dalam bdiang keamanan informasi. Karakteristik yang menarik dari chaos adalah sensitivitasnya terhadap nilai awal (initial value). Jika nilai awal sistem chaos diubah sedikit saja, misalnya sebesar $10^{-10}$, maka bila sistem chaos tersebut diiterasikan sejumlah kali, hasil iterasinya berbeda signifikan dengan sebelumnya. Sensisitivitas ini sangat berguna di dalam kriptografi karena bersesuaian dengan prinsip diffusion dari Shannon dalam merancang sebuah algoritma kriptografi (Schneier, 1996). Dengan prinsip 


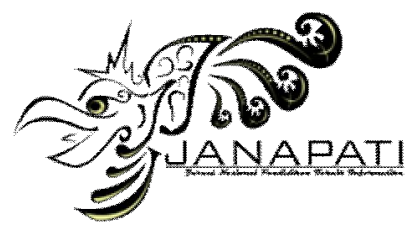

ISSN 2089-8673

Jurnal Nasional Pendidikan Teknik Informatika (JANAPATI)

Volume 1, Nomor 3, Desember 2012

diffusion ini maka pengubahan satu bit nilai awal chaos dapat menyebabkan cipherteks tetap tidak berhasil didekripsi. Dua buah fungsi chaos yang digunakan di dalam algoritma ini adalah Logistic Map dan Arnold Cat Map.

\subsection{Logistic Map}

Logistic Map adalah fungsi chaos satu dimensi yang telah digunakan secara luas, yang didefinsikan sebagai

$$
x_{i+1}=\mu x_{i}\left(1-x_{i}\right)
$$

Nilai-nlai $x_{i}$ adalah bilangan riil di dalam selang $(0,1)$, sedangkan $\mu$ adalah parameter fungsi yang menyatakan laju pertumbuhan yang nilainya di dalam selang $(0,4]$. Logistic Map akan bersifat chaos bilamana $3.5699456 \leq \mu \leq 4$ (Hongmei, 2010). Untuk memulai iterasi Logistic Map diperlukan nilai awal $x_{0}$. Perubahan sedikit saja pada nilai awal ini (misalnya sebesar $10^{-10}$ ) akan menghasilkan nilai-nilai chaos yang berbeda secara signifikan setelah Logistc Map diiterasi sejumlah kali. Di dalam sistem kriptografi simetri, nilai awal chaos, $x_{0}$, dan parameter $\mu$ berperan sebagai kunci rahasia. Nilai-nilai acak yang dihasilkan dari persamaan (1) tidak pernah berulang kembali sehingga Logistic Map dikatakan tidak mempunyai periode.

\subsection{Arnold Cat Map}

Arnold Cat Map (ACM) merupakan fungsi chaos dwimatra dan bersifat reversible. Fungsi chaos ini ditemukan oleh Vladimir Arnold pada tahun 1960, dan kata "cat" muncul karena dia menggunakan citra seekor kucing dalam eksperimennya.

$A C M$ mentransformasikan koordinat $(x, y)$ di dalam citra yang berukuran $N \times N$ ke koordinat baru $\left(x^{\prime}, y^{\prime}\right)$. Persamaan iterasinya adalah

$$
\left[\begin{array}{l}
x_{i+1} \\
y_{i+1}
\end{array}\right]=\left[\begin{array}{cc}
1 & b \\
c & b c+1
\end{array}\right]\left[\begin{array}{l}
x_{i} \\
y_{i}
\end{array}\right] \bmod (N)
$$

yang dalam hal ini $\left(x_{i}, y_{i}\right)$ adalah posisi pixel di dalam citra, $\left(x_{i+1}, y_{i+1}\right)$ posisi pixel yang baru setelah iterasi ke- $i ; b$ dan $c$ adalah integer positif sembarang. Determinan matriks $\left[\begin{array}{cc}1 & b \\ c & b c+1\end{array}\right]$ harus sama dengan 1 agar hasil transformasinya bersifat area-preserving, yaitu tetap berada di dalam area citra yang sama. ACM termasuk pemetaan yang bersifat satu-ke-satu karena setiap posisi pixel selalu ditransformasikan ke posisi lain secara unik. ACM diiterasikan sebanyak $m$ kali dan setiap iterasi menghasilkan citra yang acak. Nilai $b, c$, dan jumlah iterasi $m$ dapat dianggap sebagai kunci rahasia.

Proses yang terjadi di dalam setiap iterasi ACM adalah pergeseran (shear) dalam arah $y$, kemudian dalam arah $x$, dan semua hasilnya (yang mungkin berada di luar area gambar) dimodulokan dengan $N$ agar tetap berada di dalam area gambar (area preserving)

Setelah $A C M$ diiterasi sebanyak $m$ kali, maka terdapat $T$ sedemikian sehingga $\left(x_{T}, y_{T}\right)=(x, y)$, yang dalam hal ini nilai $T$ bergantung pada $b, c$, dan ukuran $N$ (We-bin, 2009). Ini berarti sesudah $A C M$ diiterasi sebanyak $T$ kali, maka hasil iterasinya kembali ke citra semula, sehingga dikatakan $A C M$ besifat reversible dan periodenya adalah $T$. Menurut Struss (2009), penelitian Freeman J. Dyson dan Harold Falk menemukan bahwa $T<3 N$. Gambar 1 memperlihatkan iterasi $A C M$ 


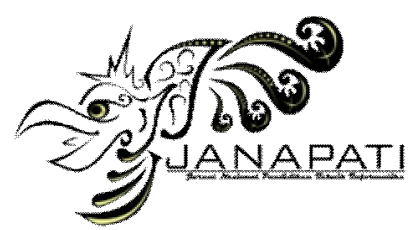

ISSN 2089-8673

Jurnal Nasional Pendidikan Teknik Informatika (JANAPATI)

Volume 1, Nomor 3, Desember 2012

terhadap citra 'burung'. Pada iterasi ketiga hasilnya sudah terlihat seperti citra acak, semakin banyak iterasinya citra hasil semakin acak (dalam hal ini ACM telah berada dalam fase chaos). Jika proses iterasi diteruskan maka hasilnya kembali menuju citra semula. Pada contoh ini citra 'burung' kembali ke bentuk semula pada iterasi ke-192 sehingga dikatakan periodenya adalah $T=192$.

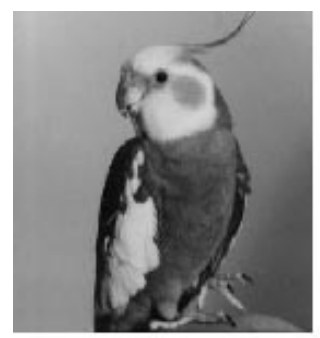

Citra awal

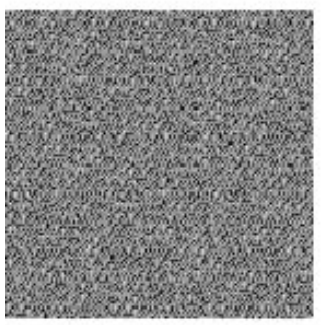

99

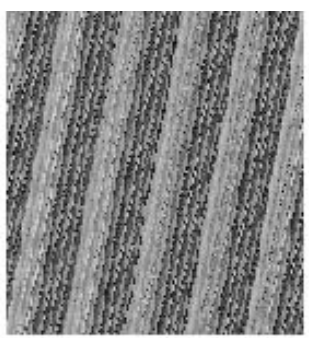

1

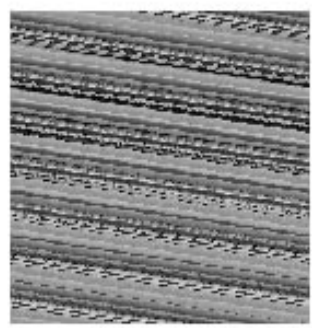

191

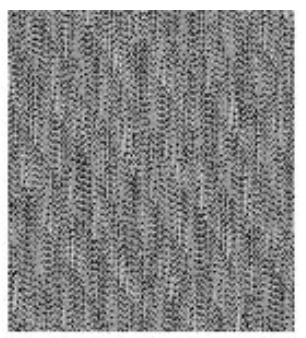

3

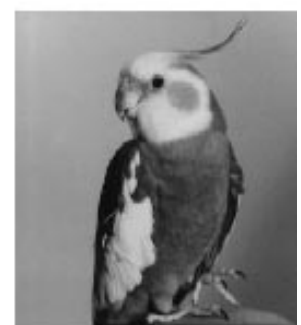

192

Gambar 1. Iterasi ACM pada citra 'burung' dengan periode $T=192$

Seperti umumnya fungsi chaos yang bersifat deterministik, citra yang sudah teracak oleh ACM dapat direkonstruksi menjadi citra semula dengan menggunakan kunci yang sama $(b, c$, dan $m)$. Persamaan iterasinya adalah

$$
\left[\begin{array}{l}
x_{i} \\
y_{i}
\end{array}\right]=\left[\begin{array}{cc}
1 & b \\
c & b c+1
\end{array}\right]^{-1}\left[\begin{array}{l}
x_{i+1} \\
y_{i+1}
\end{array}\right] \bmod (N)
$$

Setelah iterasi terakhir citra hasil sama sepert citra semula. Proses dekripsipun selesai.

\section{Algoritma Enkripsi/Dekripsi yang Diusulkan}

Meskipun citra hasil transformasi Arnold Cat Map sudah teracak dan tidak bisa dikenali lagi, namun enkripsi dengan Arnold Cat Map saja tidak cukup aman, karena sifat periodik ACM dapat menghasilkan kembali citra semula. Dengan proses hack sederhana nilai $b$ dan $c$ dapat ditemukan melalui operasi brute force (Yu, 2006). Selain itu ACM hanya mengubah posisi pixel di dalam citra tetapi tidak mengubah nilai pixel. Oleh karena itu, nilai-nilai pixe/ hasil permutasi dengan $A C M$ perlu diubah nilainya melalui operasi substitusi dengan Logistic Map. 


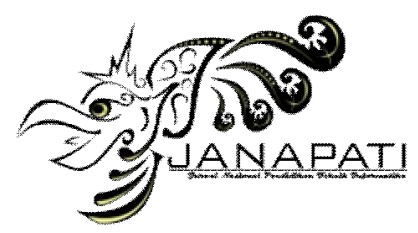

ISSN 2089-8673

Jurnal Nasional Pendidikan Teknik Informatika (JANAPATI)

Volume 1, Nomor 3, Desember 2012

Tanpa kehilangan generalisasi, di bawah ini diuraikan rincian algoritma enkripsi yang diusulkan untuk citra grayscale yang berukuran $N \times N$. Pada dasarnya algoritma enkripsi dibagi menjadi dua tahapan: tahap pengacakan dan tahap encoding.

\subsection{Enkripsi: Tahap Pengacakan}

Pada tahap ini dilakukan operasi permutasi dengan ACM yang bertujuan mengacak susunan pixel-pixel di dalam citra.

Masukan: citra $l, b, c$, dan $m$

Keluaran: citra teracak $P$

Proses: Iterasikan $A C M$ pada persamaan (1) dengan parameter $b$ dan $c$ terhadap citra / sebanyak $m$ kali. Hasil iterasi terakhir adalah citra $\rho$

Pseudo-code algoritmanya adalah sebagai berikut:

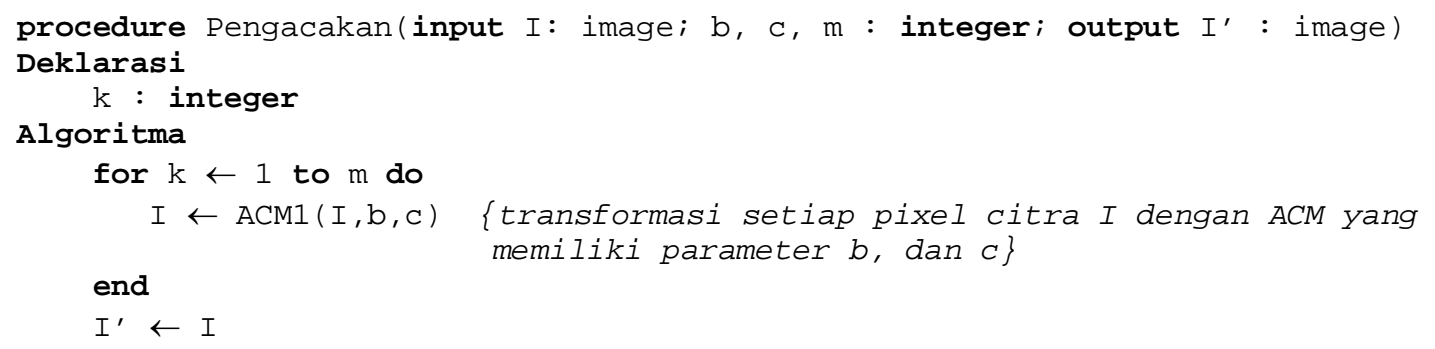

\subsection{Enkripsi: Tahap Encoding}

Pada tahap ini dilakukan pengubahan nilai-nilai pixel dari citra hasil pengacakan dengan operasi substitusi.

Masukan: citra $l^{\prime}, x_{0}$, dan $\mu$ Keluaran: citra terenkripsi (cipher-image) $C$

Proses: Pixel-pixel citra $P=\left(p_{1}, p_{2}, \ldots, p_{N \times N}\right)$ di-XOR-kan dengan keystream (integer) (yang dibangkitkan dari Logistic Map dengan nilai awal $x_{0}$ dan parameter $\mu$ ). Skema enkripsinya adalah dengan mode yang diadopsi dari cipher block chaining (Schneier, 1996) seperti yang ditunjukkan pada Gambar 2. Pixel-pixel hasil enkripsi adalah $C=\left(c_{1}, c_{2}, \ldots, c_{N \times N}\right)$. Proses enkripsi ini dapat dirumuskan sebagai

$$
c_{i}=\left(p_{i} \oplus c_{i-1}\right) \oplus k_{i}
$$




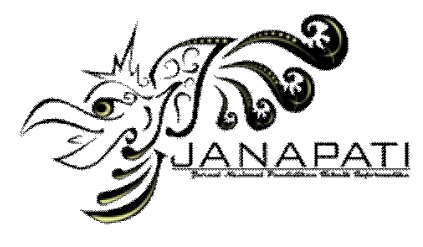

ISSN 2089-8673

Jurnal Nasional Pendidikan Teknik Informatika (JANAPATI)

Volume 1, Nomor 3, Desember 2012

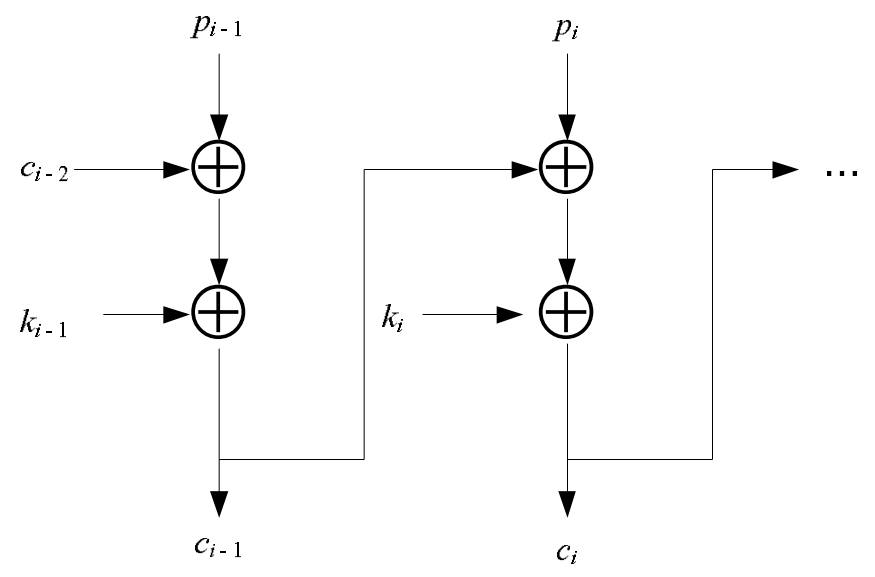

Gambar 2. Skema enkripsi

Untuk enkripsi pixel pertama diperlukan $c_{0}$ yang dalam hal ini $c_{0}$ adalah initialization vector atau $I V$ (pada algoritma ini $I V=0$ ). IV tidak perlu rahasia tetapi harus sama nilainya pada proses dekripsi.

Karena nilai-nilai acak yang dibangkitkan dari Logistic Map berupa bilangan riil, nilai tersebut harus ditransformasikan menjadi integer. Transformasi yang sederhana adalah dengan mengambil bagian desimal dari bilangan riil, membuang angka nol yang tidak signifikan, lalu mengekstrak $t$ digit integer. Sebagai contoh, misalkan $x_{i}=0.003176501$ dan $t=4$, maka diambil bagian desimalnya yaitu 003176501, buang dua buah nol yang tidak signifikan di depannya, lalu ekstrak sebanyak 4 digit yaitu 3176. Inilah keytream yang akan di-XOR-kan dengan pixel ke-i. Karena nilainilai pixel berada di dalam rentang integer [0, 255], maka sebelum di-XOR-kan keystream dimodulus-kan dengan 256. Jadi, pada contoh ini $k_{i}=3176 \bmod 256=104$.

Pseudo-code algoritmanya adalah sebagai berikut:

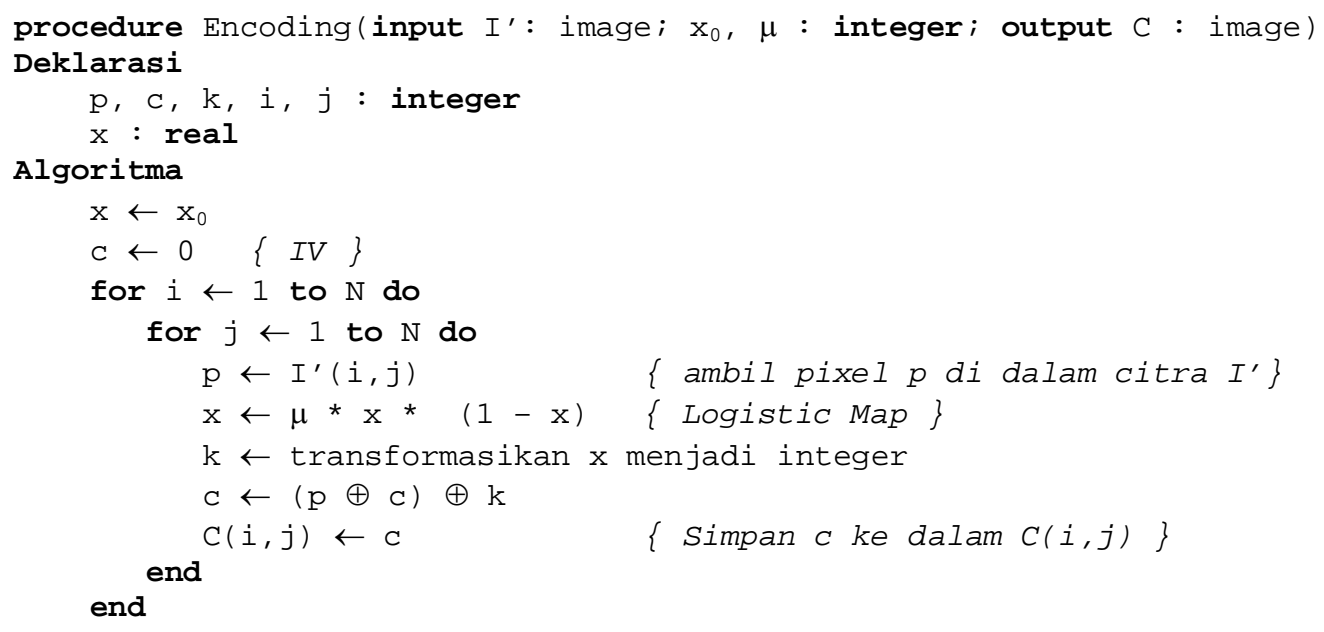




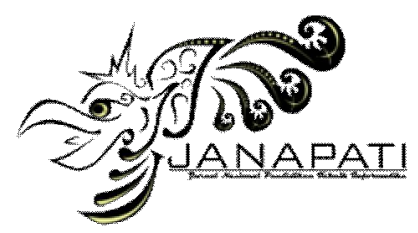

ISSN 2089-8673

Jurnal Nasional Pendidikan Teknik Informatika (JANAPATI)

Volume 1, Nomor 3, Desember 2012

Algoritma dekripsi berkebalikan dengan algoritam enkripsi. Urutannya adalah tahap decoding terlebih dahulu, kemudian tahap balik-pengacakan. Penjelasannya adalah seperti di dalam upa-bab di bawah ini.

\subsection{Dekripsi: Tahap Decoding}

Pada tahap ini dilakukan pengubahan nilai-nilai pixel dari cipher-image dengan operasi substitusi. Algoritmanya adalah sebagai berikut:

Masukan: citra $C, x_{0}$, dan $\mu$

Keluaran: citra hasil decoding, $P$

Proses: Pixel-pixel citra $C=\left(c_{1}, c_{2}, \ldots, c_{N \times N}\right)$ di-XOR-kan dengan keystream (integer) (yang dibangkitkan dari Logistic Map dengan nilai awal $x_{0}$ dan parameter $\mu$ ). Skema dekripsinya adalah dengan mode yang ditunjukkan pada Gambar 3. Pixel-pixel hasil dekripsi adalah $P=\left(p_{1}, p_{2}, \ldots\right.$, $\left.p_{N \times N}\right)$. Proses dekripsi ini dapat dirumuskan sebagai

$$
p_{i}=\left(c_{i} \oplus k_{1}\right) \oplus c_{i-1}
$$



Gambar 3. Skema dekripsi

Pseudo-code algoritmanya adalah sebagai berikut:

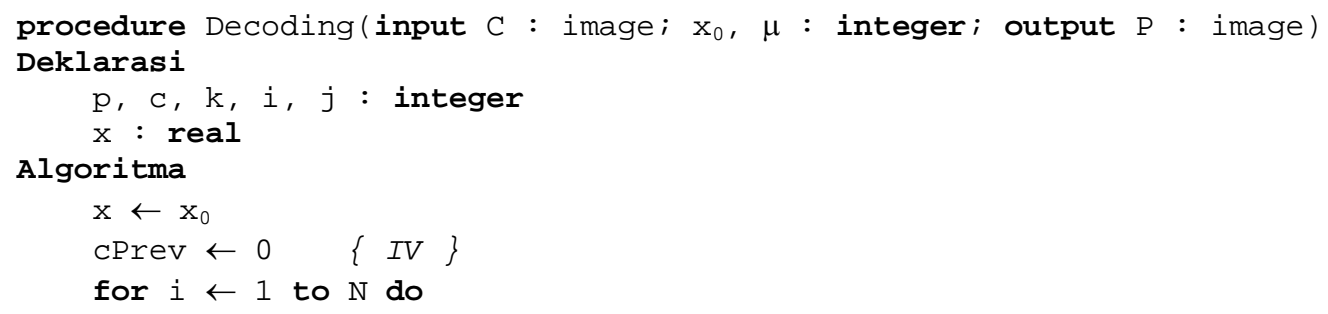




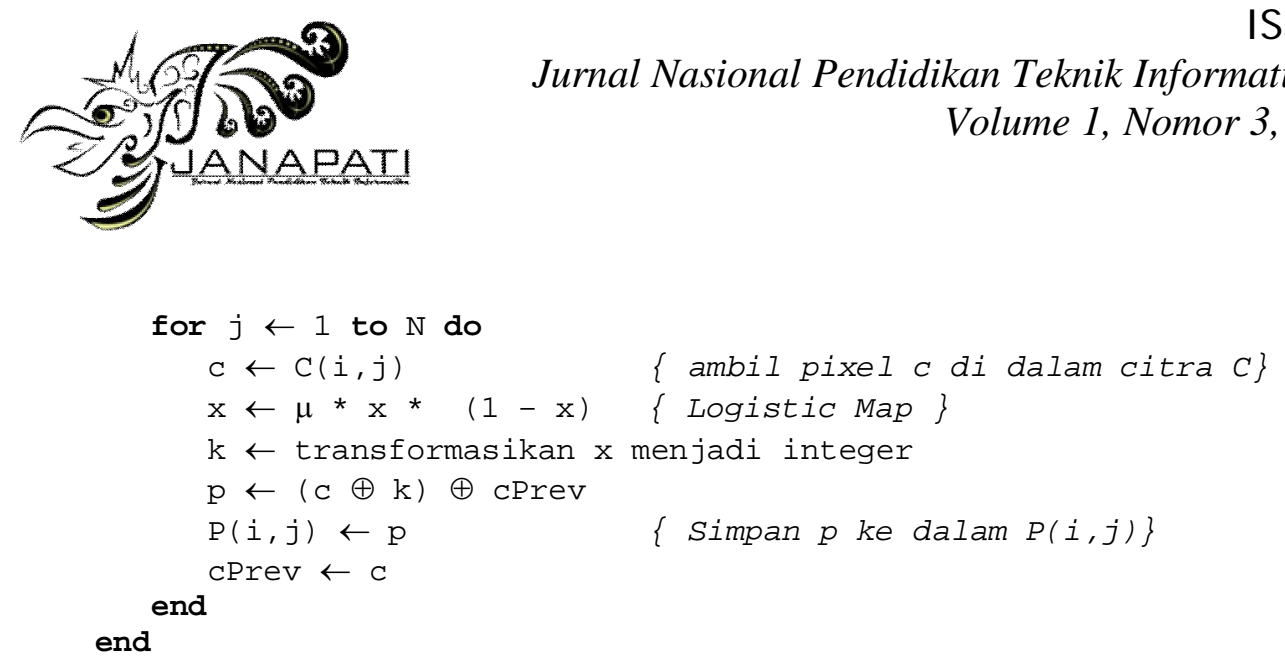

ISSN 2089-8673

atika (JANAPATI)

Desember 2012

\subsection{Dekripsi: Tahap Balik-Acak}

Pada tahap ini dilakukan operasi permutasi dengan invers $A C M$ yang bertujuan mengembalikan susunan pixel-pixel menjadi susunan semula

Masukan: citra $P, b, c$, dan $m$

Keluaran: citra semula I

Proses: Iterasikan $A C M$ pada persamaan (2) dengan parameter $b$ dan $c$ terhadap citra $P$ sebanyak $m$ kali. Hasil iterasi terakhir adalah citra semula, I.

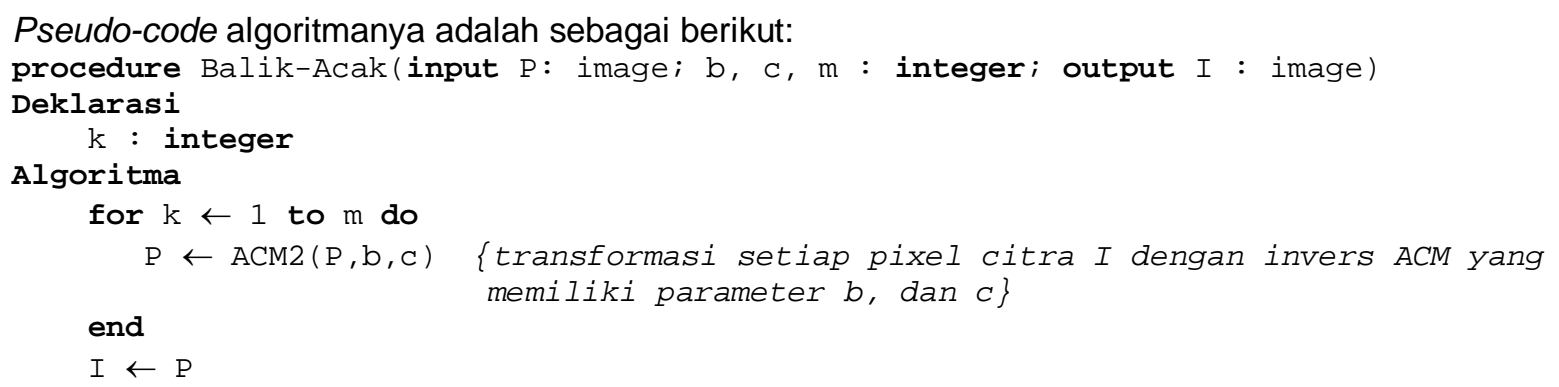

\subsection{Enkripsi dan Dekripsi pada Citra Berwarna}

Pixel-pixel pada citra berwarna disusun oleh tiga buah kanal warna, yaitu red $(R)$, green $(G)$, dan blue $(B)$. Oleh karena itu, tahap pengacakan dan tahap encoding dilakukan secara terpisah untuk masing-masing kanal. Jadi proses enkripsi/dekripsinya tiga kali lebih lama daripada citra grayscale.

\section{Eksperimen dan Pembahasan Hasil}

Algoritma enkripsi/dekripsi yang telah didekripsikan di atas disimulasikan dengan dengan menggunakan kakas Matlab. Eksperimen dilakukan pada dua buah citra uji, masing-masing citra grayscale dan citra berwarna. Kedua buah citra tersebut merupakan citra uji standard di dalam bidang pengolahan citra, yaitu citra 'couple' $(512 \times 512)$ dan citra 'yacht' $(512 \times 512)$, seperti ditunjukkan pada Gambar 4(a) dan 4(b). Parameter kunci yang dipakai di dalam eksperimen adalah: $b=32, c=41, r=3.9728, x_{0}=0.3$, dan $m=5$. 


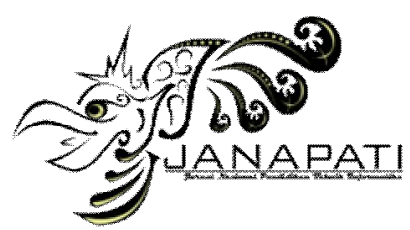

ISSN 2089-8673

Jurnal Nasional Pendidikan Teknik Informatika (JANAPATI)

Volume 1, Nomor 3, Desember 2012

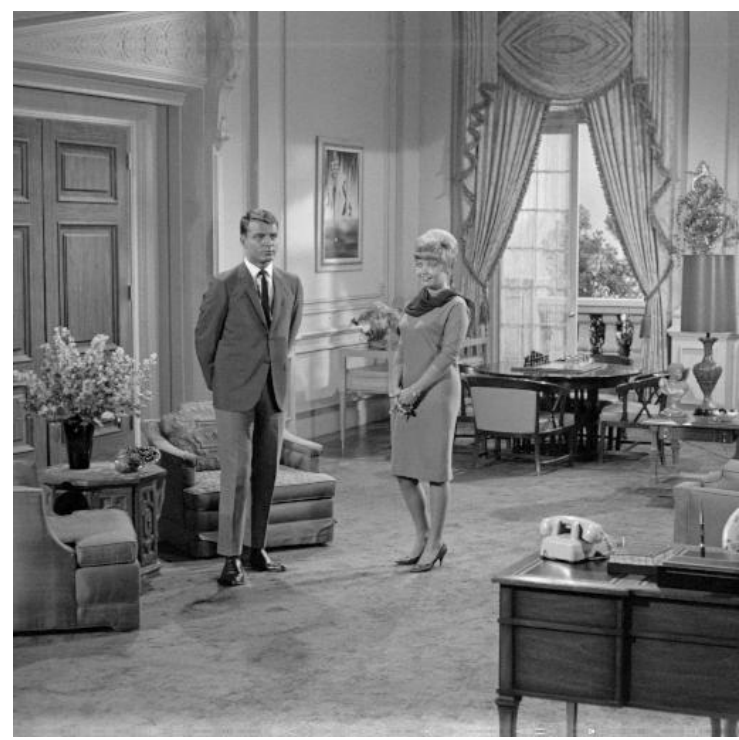

(a)

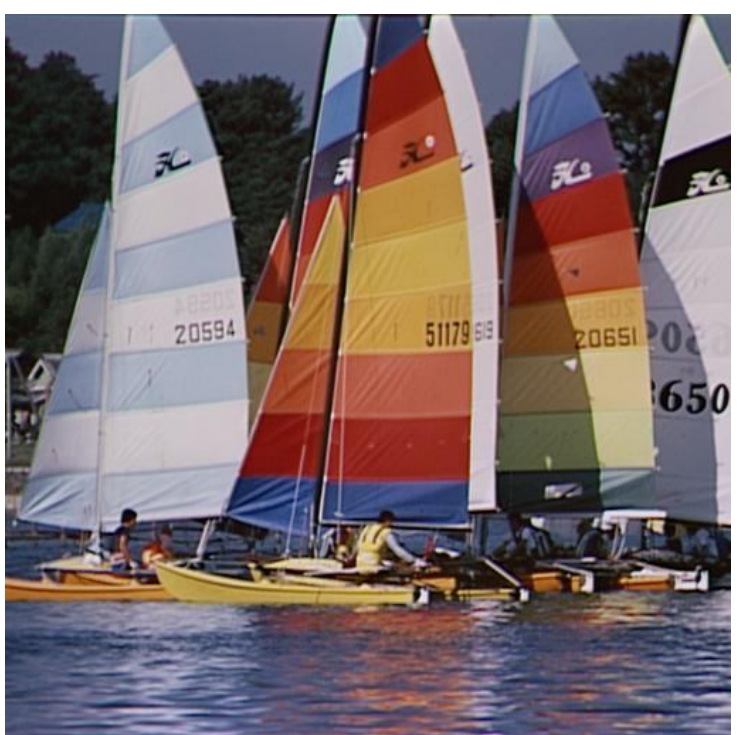

(b)

Gambar 4. Dua buah citra uji: (a) 'couple' (grayscale) (b) 'yacht' (berwarna)

\subsection{Hasil Enkripsi dan Dekripsi}

Citra hasil enkripsi (cipher-image) masing-masing diperlihatkan pada Gambar 5(a) dan 5(b). Citra hasil enkripsi terlihat sudah tidak dapat dikenali lagi dan tampak seperti citra acak. Dekripsi terhadap cipher-image dengan parameter kunci yang sama menghasilkan kembali tepat seperti citra semula (Gambar 5(c) dan 5(d)). 


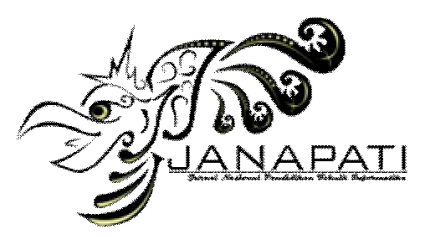

ISSN 2089-8673

Jurnal Nasional Pendidikan Teknik Informatika (JANAPATI)

Volume 1, Nomor 3, Desember 2012

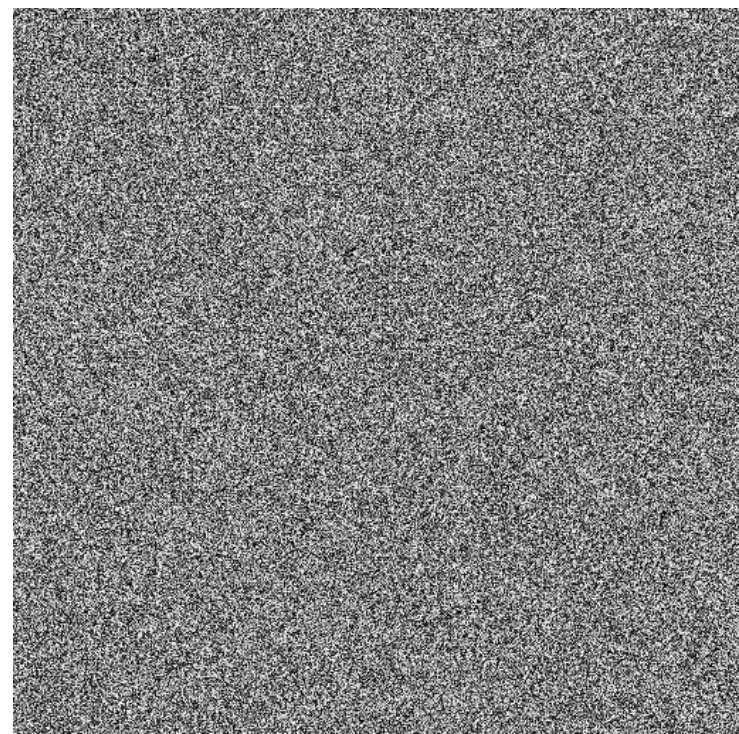

(a)

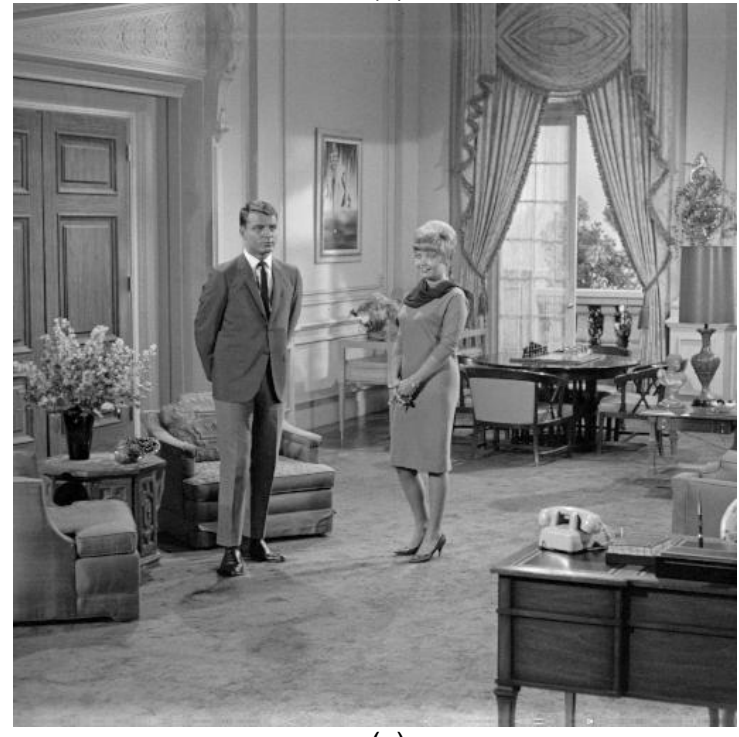

(c)

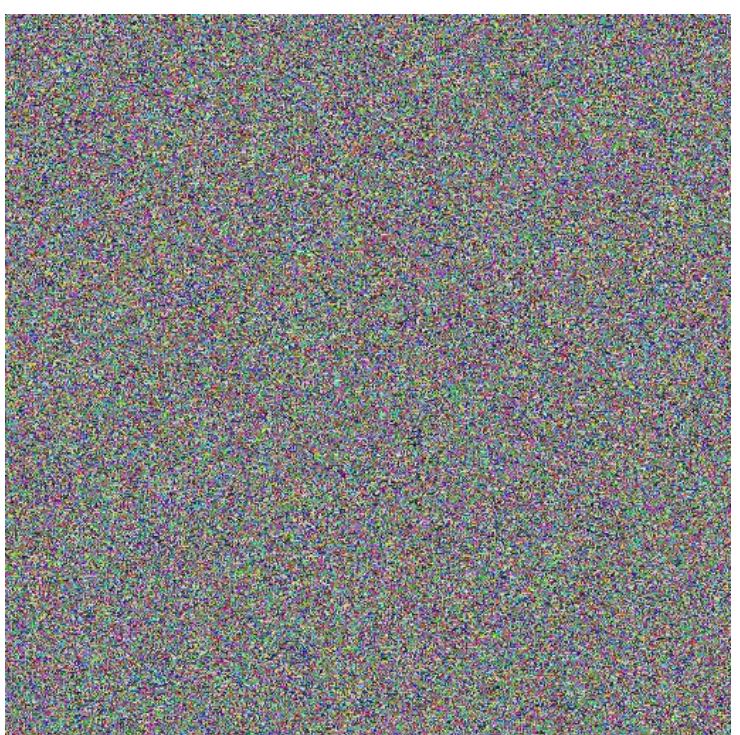

(b)

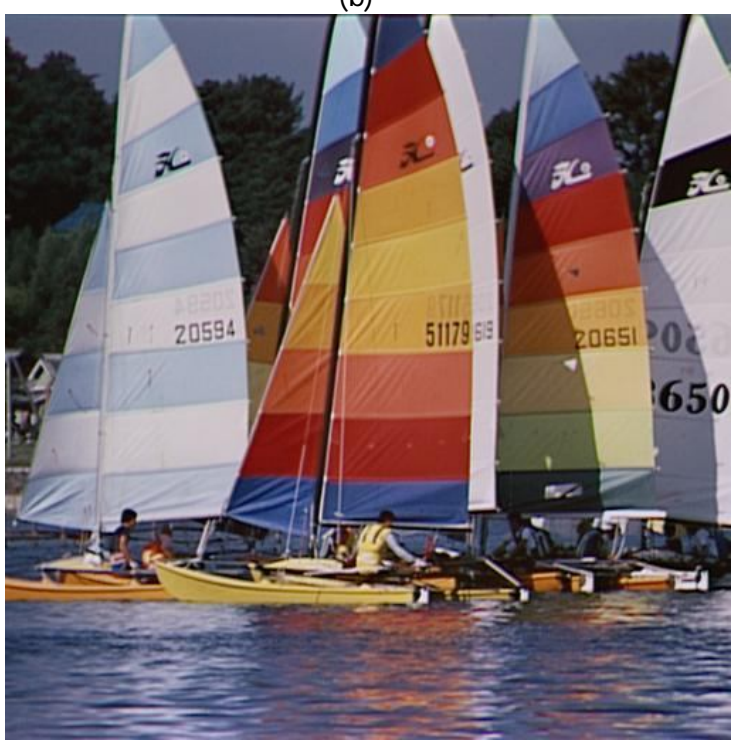

(b)

Gambar 5. (a) cipher-image dari 'couple'; (b) cipher-image dari 'yacht'; (c) hasil dekripsi citra 'couple'; (d) hasil dekripsi citra 'yacht'

\subsection{Analisis Histogram}

Histogram merupakan salah satu fitur citra yang penting, sebab sebuah histogram memperlihatkan distribusi intensitas pixel-pixel di dalam citra tersebut. Dalam melakukan serangan dengan teknik analisis statistik, penyerang menggunakan histogram untuk menganalisis frekuensi kemunculan intensitas pixel untuk mendeduksi kunci atau pixel-pixel di dalam plain-image. Agar serangan dengan analisis statistik tidak dimungkinkan, maka di dalam enkripsi citra penting untuk menghasilkan histogram cipher-image yang tidak memiliki kemiripan secara statistik dengan 


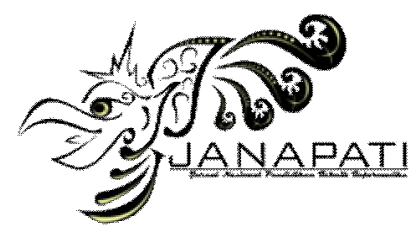

ISSN 2089-8673

Jurnal Nasional Pendidikan Teknik Informatika (JANAPATI)

Volume 1, Nomor 3, Desember 2012

histogram plain-image. Oleh karena itu, pixel-pixel di dalam cipher-image seharusnya memiliki distribusi yang (relatif) uniform atau ditunjukkan dengan histogram yang terlihat datar (flat).

Gambar 6(a) memperlihatkan histogram citra 'couple' dan Gambar 6(b) adalah histogram cipherimage-nya. Histogram cipher-image terlihat datar dan berbeda dengan histogram plain-image.

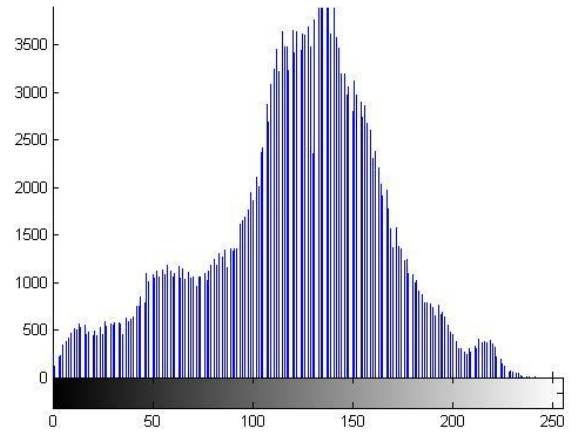

(a)

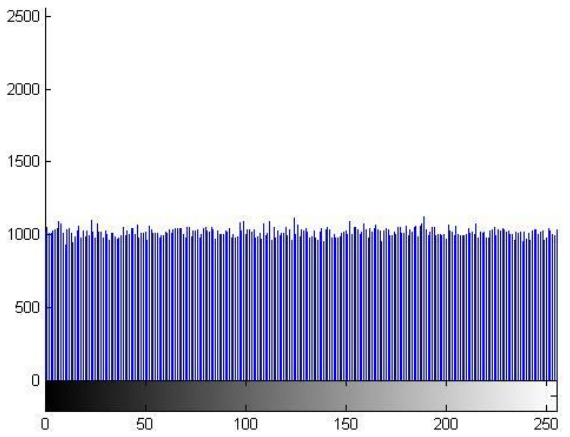

(b)

Gambar 6. (a) Histogram citra 'couple' (plain-image) dan (b) histogram cipher-image.

Gambar 7(a) sampai 7(c) adalah histogram citra 'yacht' (plain-image) untuk setiap kanal warna $R G B$, sedangkan Gambar 7(d) sampai 7(f) adalah histogram masing-masang kanal warna pada cipher-image. Seperti pada citra 'couple', histogram setiap kanal RGB pada cipher-image juga berbentuk flat atau terdistribusi uniform.



(a)

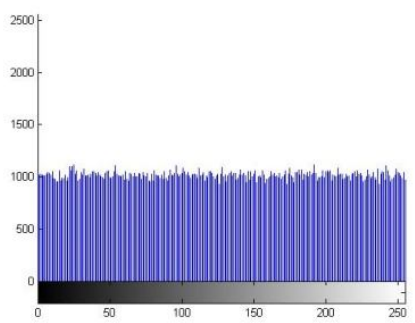

(d)

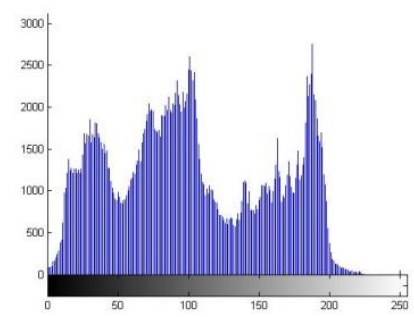

(b)

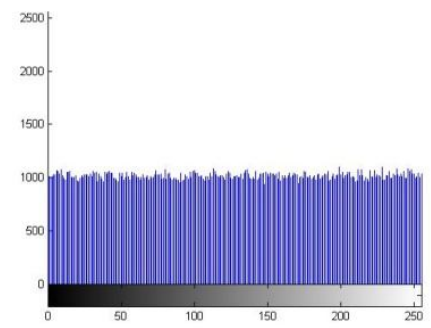

(e)

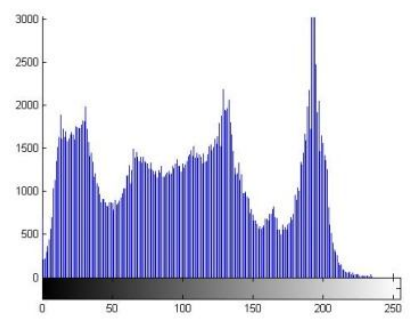

(c)

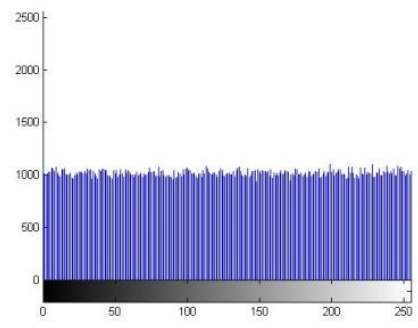

(f)

Gambar 7. (a)-(c) Histogram citra 'yacht' (plain-image) untuk masing-masing kanal RGB; dan (d)-(f) histogram cipher-image untuk setiap kanal 


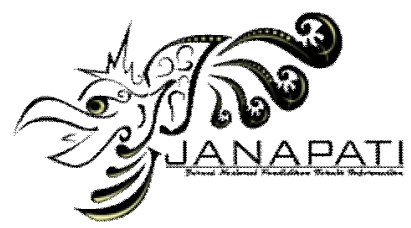

ISSN 2089-8673

Jurnal Nasional Pendidikan Teknik Informatika (JANAPATI)

Volume 1, Nomor 3, Desember 2012

\subsection{Analisis Korelasi}

Korelasi adalah besaran statistik yang menyatakan kekuatan hubungan linier antara dua peubah acak (Xiang, 2007). Koefisien korelasi $\left(r_{x y}\right)$ dari dua buah peubah acak diskrit yang masingmasing beranggotakan $n$ elemen dihitung dengan rumus berikut (Hongmei, 2010):

$$
r_{x y}=\frac{\operatorname{cov}(x, y)}{\sqrt{D(x) D(y)}}
$$

yang dalam hal ini

$$
\begin{array}{ll}
\operatorname{cov}(x, y)=\frac{1}{n} \sum_{i=1}^{n}\left[x_{i}-E(x)\right]\left[y_{i}-E(y)\right] & \text { (kovariansi) } \\
D(x)=\frac{1}{n} \sum_{i=1}^{n}\left[x_{i}-E(x)\right]^{2} & \text { (standard deviasi) } \\
E(x)=\frac{1}{n} \sum^{n} x_{i} & \text { (rata-rata) }
\end{array}
$$

Nilai koefisien korelasi tidak dapat melebihi 1 dalam harga mutlak. Nilai koefisien korelasi +1 menyatakan hubungan linier (korelasi) sempurna yang menaik, nilai koefisien korelasi -1 menyatakan hubungan linier (korelasi) sempurna yang menurun, sedangkan antara -1 dan +1 menyatakan derajat ketergantungan linier antara dua peubah. Nilai koefisien yang dekat dengan -1 atau +1 menyatakan hubungan linier yang kuat antara $x$ dan $y$, sedangkan nilai koefisien yang dekat dengan 0 menyatakan hubungan linier yang lemah.

Pada kebanyakan citra plain-image, koefisien korelasi antara pixel-pixel bertetangga biasanya tinggi (mendekati +1 atau -1). Tujuan enkripsi citra adalah menghilangkan korelasi antara pixel-pixel tersebut atau membuat koefisien korelasinya mendekati nol.

Untuk menyelidiki korelasi pada plain-image dan cipher-image, maka dihitung koefisien korelasi antara dua pixel yang bertetangga secara horizontal $[f(i, j)$ dan $f(i, j+1)]$, dua pixel yang bertetangga secara vertkal $[f(i, j)$ dan $f(i+1, j)]$, dan dua pixel yang bertetangga secara diagonal $f(i, j)$ dan $f(i+1$, $j+1)$ ], baik pada plain-image maupun pada cipher-image.

Di dalam eksperimen ini dipilih secara acak 1000 pasang pixel bertetangga pada setiap arah (vertikal, horizontal, dan diagonal) dari citra 'couple' beserta citra hasil enkripsinya. Koefisien korelasi dihitung dengan persamaan (5), yang dalam hal ini $x$ dan $y$ adalah nilai keabuan dari dua pixel bertetangga. Hasil eksperimen diperlihatkan pada Tabel 1.

Tabel 1. Perbandingan koefisien korelasi antara dua pixe/ bertetangga

\begin{tabular}{|l|l|l|l|}
\hline Koefisien korelasi & \multicolumn{1}{|c|}{ Horizontal } & \multicolumn{1}{|c|}{ Vertikal } & \multicolumn{1}{c|}{ Diagonal } \\
\hline Plain-image & 0.9364 & 0.9422 & 0.9046 \\
\hline Cipher-image & -0.0142 & 0.0244 & 0.0471 \\
\hline
\end{tabular}




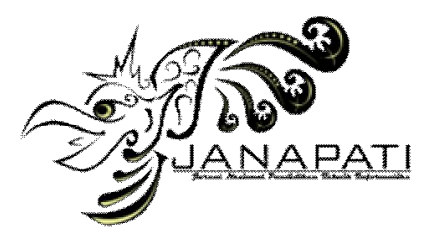

ISSN 2089-8673

Jurnal Nasional Pendidikan Teknik Informatika (JANAPATI)

Volume 1, Nomor 3, Desember 2012

Dari Tabel 1 dapat dilihat bahwa koefisien korelasi pada pixel-pixel bertetangga pada setiap arah di dalam plain-image nilainya berada di sekitar angka 1, yang mengindikasikan korelasi yang kuat diantara pixel-pixel tersebut, tetapi pada cipher-image koefisien korelasinya mendekati nol, yang mengindikasikan pixel-pixel yang bertetangga tidak lagi berkorelasi.

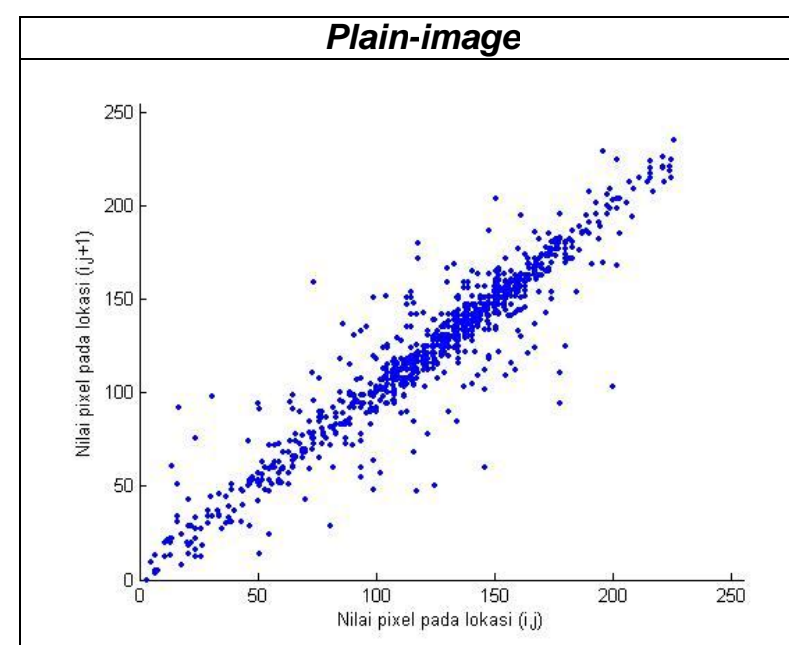

(a) Horizontal

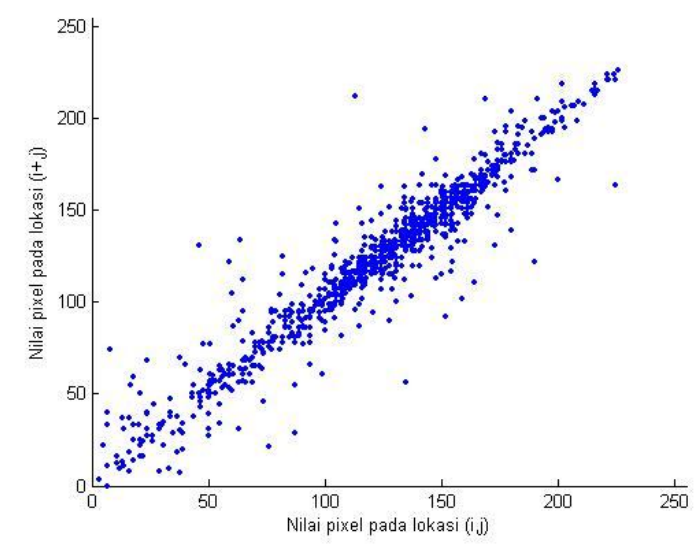

(b) Vertikal

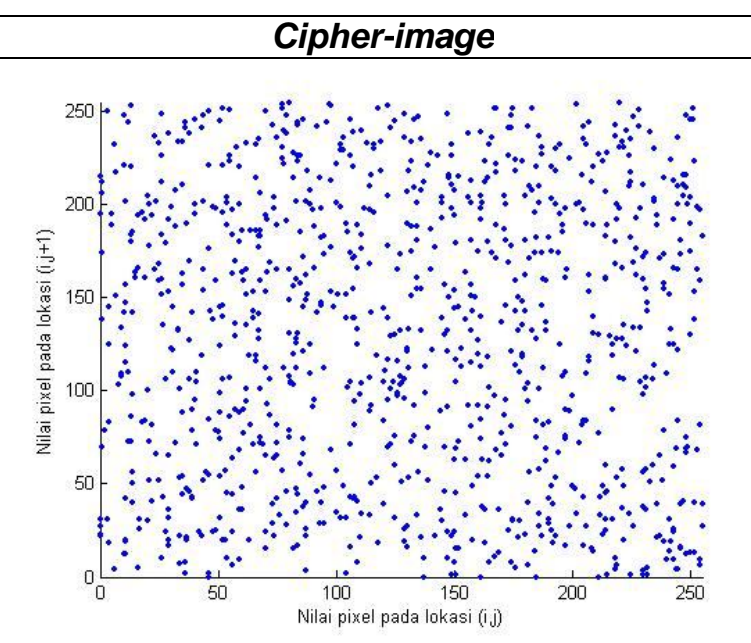

(d) Horizontal

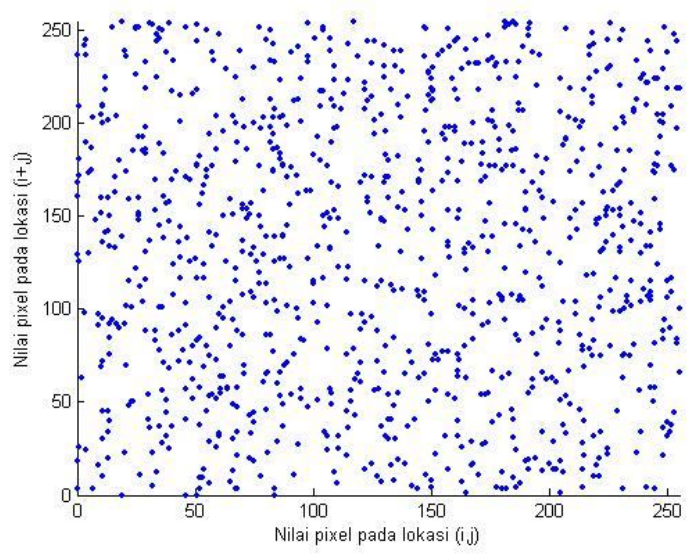

(e) Vertikal 


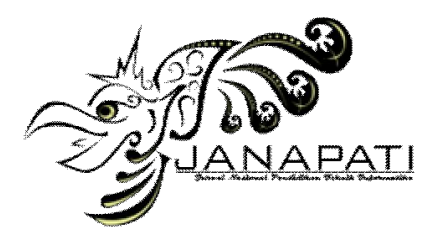

ISSN 2089-8673

Jurnal Nasional Pendidikan Teknik Informatika (JANAPATI)

Volume 1, Nomor 3, Desember 2012

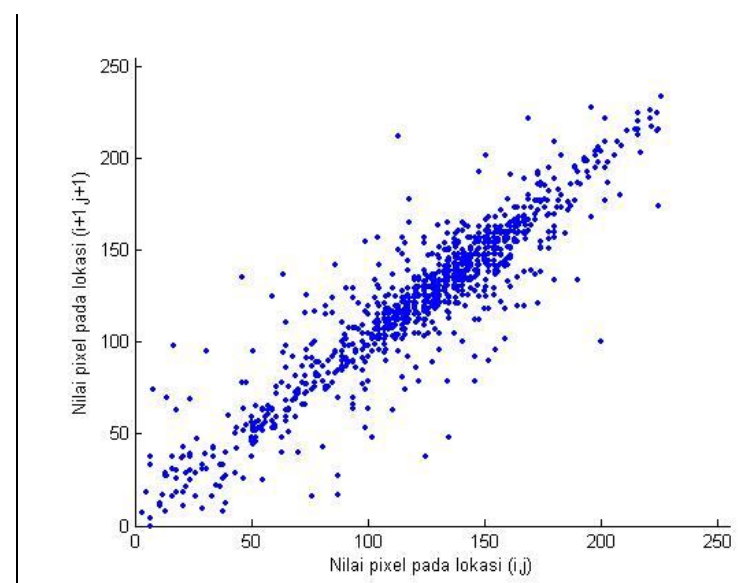

(c) Diagonal

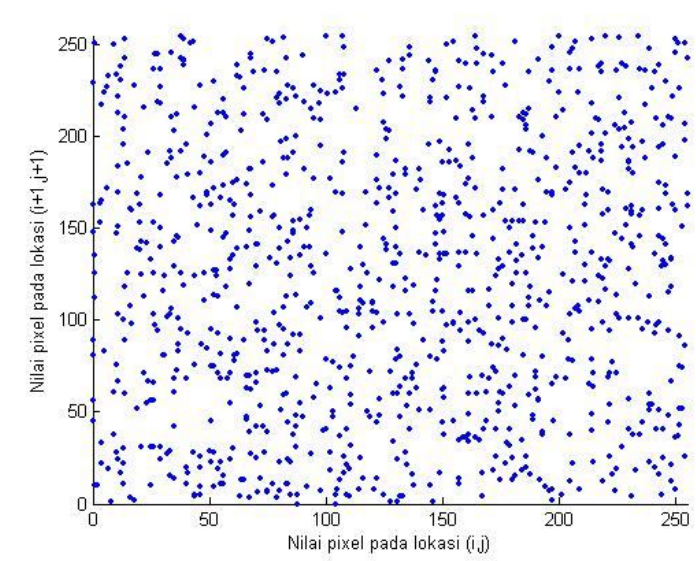

(f) Diagonal

Gambar 8. Distribusi korelasi pixel-pixe/ bertetangga pada plain-image dan cipher-image

Untuk memperlihatkan situasi yang lebih jelas mengenai korelasi, Gambar 8 memperlihatkan distribusi korelasi pixel-pixel yang bertetangga pada masing-masing plain-image (kolom kiri) dan cipher-image (kolom kanan). Pada plain-image, pixel-pixel yang bertetangga nilai-nilainya berada di sekitar garis diagonal $45^{\circ}$, yang mengindikasikan korelasi yang kuat antara pixel-pixel tersebut. Sebaliknya, pada cipher-image nilai-nilai pixel tersebar merata di seluruh area bidang datar, yang mengindikasikan pixel-pixel di dalamnya tidak lagi berkorelasi.

\subsection{Analisis Sensitivitas}

Untuk mengetahui sensitivitas chaos terhadap perubahan kecil nilai awal, maka dilakukan eksperimen dengan mengubah nilai awal logistic map $\left(\mathrm{x}_{0}\right)$ sebesar $\Delta$ menjadi $x_{0}+\Delta$. Selanjutnya cipher-image didekripsi dengan $x_{0}+\Delta$. Misalkan $\Delta=10^{-10}$ sehingga nilai awal logistic map menjadi 0.3000000001 . Hasil dekripsi terhadap cipher-image dengan nilai awal 0.3000000001 diperlihatkan pada Gambar 9(a), yang ternyata tetap seperti citra acak (tidak kembali menjadi citra semula). Eksperimen ini menunjukkan bahwa chaos menenuhi prinsip diffusion dari Shanon (Schneier, 1996), sehingga serangan brute force akan gagal karena perubahan satu bit saja pada kunci menyebabkan hasil dekripsi tetap salah.

\subsection{Ruang Kunci}

Ruang kunci menyatakan jumlah total kunci yang berbeda yang dapat digunakan unruk enkripsi/dekripsi (Fu, 2012). Ruang kunci seharusnya cukup besar agar serangan brute-force attack menjadi tidak efisien dilakukan. Parameter kunci rahasia yang digunakan di dalam algoritma enkripsi lebih dari satu buah, yaitu $b, c, m, x_{0}$, dan $r$. Tiga parameter pertama, $b, c$, dan $m$ adalah integer positif. Matlab mendukung maksimum unsigned integer hingga 32 bit, sehingga nilai pilihan integer yang mungkin adalah sekitar $2^{32}=4.3 \times 10^{9}$. Untuk nilai awal Logistic Map $\left(x_{0}\right)$, presisi 


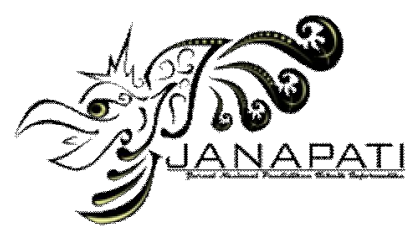

ISSN 2089-8673

Jurnal Nasional Pendidikan Teknik Informatika (JANAPATI)

Volume 1, Nomor 3, Desember 2012

komputasi untuk double-pecision 64-bit menurut standard floating-point IEEE adalah $10^{-15}$ (Fu, 2012), sehingga jumlah kemungkinan nilai $x_{0}$ adalah $10^{15}$. Dengan demikian, ruang kunci seluruhnya adalah

$$
H\left(b, c, m, x_{0}, r\right) \approx\left(4.3 \times 10^{9}\right) \times\left(4.3 \times 10^{9}\right) \times\left(10^{15}\right) \times\left(10^{15}\right) \approx 18.49 \times 10^{48}
$$

yang cukup besar bertahan terhadap serangan brute-force attack.

\section{Kesimpulan}

Di dalam makalah telah dipresentasikan sebuah algoritma enkripsi citra digital berbasis chaos yang menggabungkan teknik permutasi dan teknik substitusi. Teknik permutasi menggunakan Arnold Cat Map, dan teknik substitusi menggunakan Logistic Map.

Melalui simulasi eksperimen, algoritma ini dapat mengenkripsi sembarang citra (baik citra grayscale maupun citra berwarna) dengan baik. Citra hasil enkripsi (cipher-image) terlihat seperti citra acak dan sudah tidak dapat dikenali lagi. Analisis histogram memperlihatkan pixel-pixel di dalam cipher-image mempunyai distribusi uniform, sedangkan analisis korelasi menunjukkan bahwa pixel-pixel di dalam cipher-image tidak berkorelasi, sehingga membuat serangan dengan analisis statistik menjadi sulit.

Sifat chaos yang sensitif terhadap perubahan kecil nilai awal telah ditunjukkan dengan melakukan perubahan kecil pada kunci yang menyebabkan citra tidak berhasil diedekripsi, sehingga algoritma ini aman dari serangan exhaustive-key search attack.

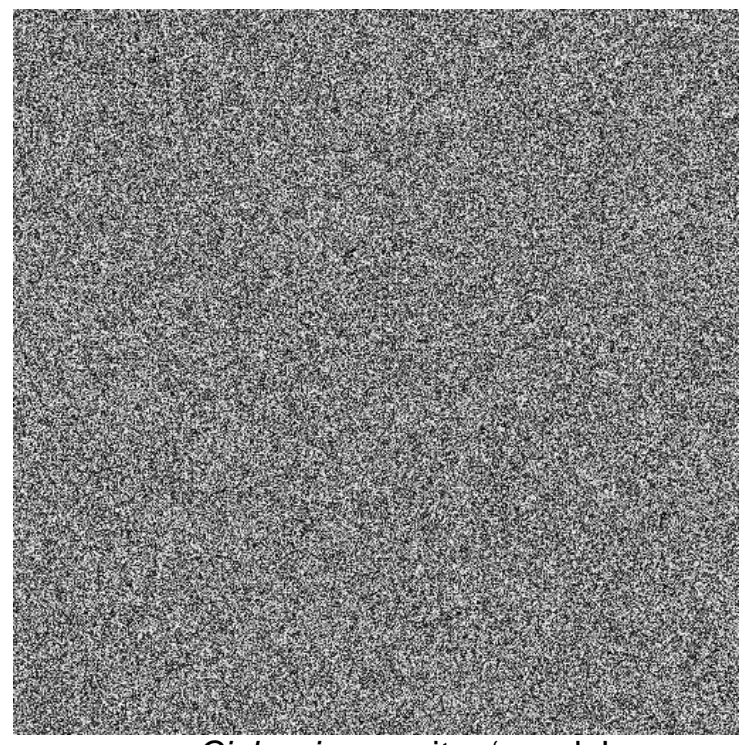

(a) Cipher-image citra 'couple'

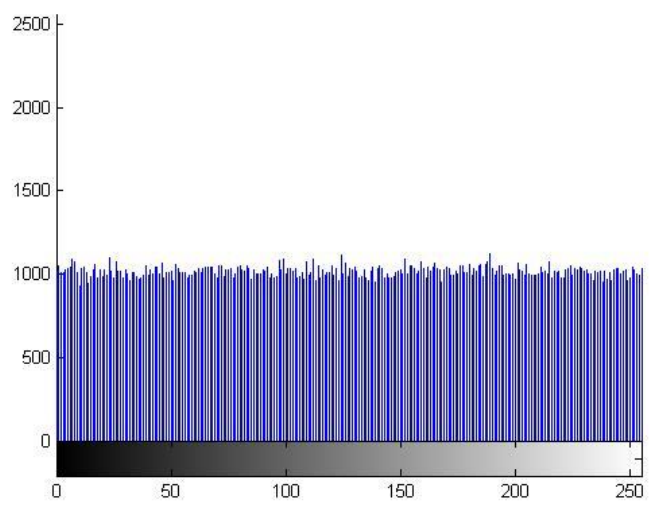

(b) Histogram dari citra (a) 


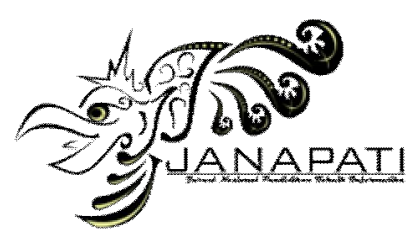

ISSN 2089-8673

Jurnal Nasional Pendidikan Teknik Informatika (JANAPATI)

Volume 1, Nomor 3, Desember 2012

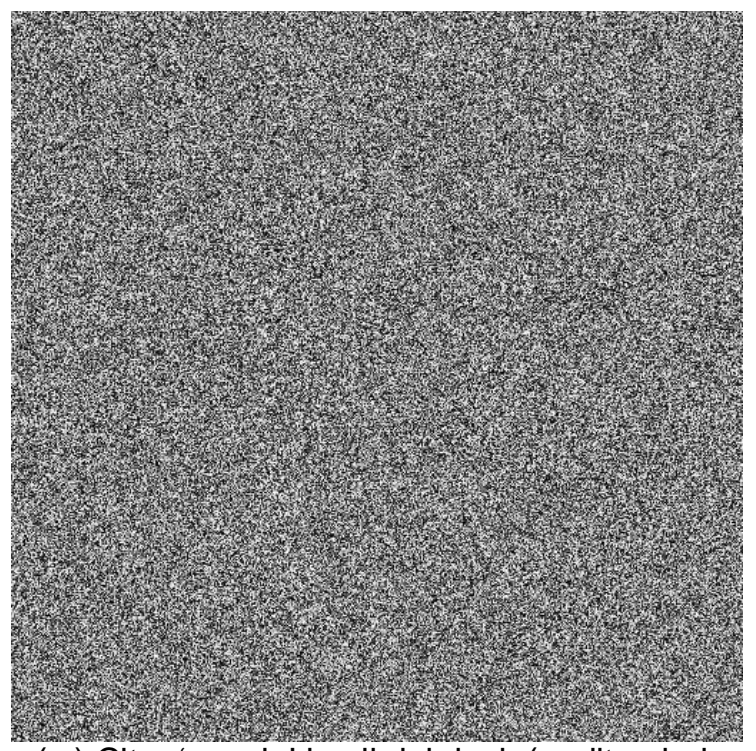

(c) Citra 'couple' hasil dekripsi ( $x_{0}$ ditambah sebesar $\Delta=10^{-10}$ )

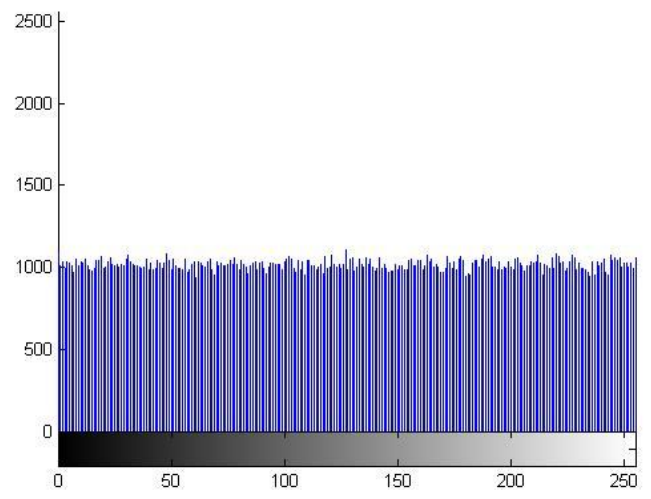

(d) Histogram dari citra (c)

Gambar 9. Hasil eksperimen dekripsi dengan pengubahan $x_{0}$ sebesar $\Delta=10^{-10}$.

\section{ACKNOWLEDGMENT}

Penelitian yang dipublikasikan di dalam makalah ini sepenuhnya didukung oleh dana Riset dan Inovasi KK 2012 (Program Riset ITB 2012).

\section{PUSTAKA}

1. Sharma, M., Kowar, M.K. (2010), Image Encryption Technique Using Chaotic Schemes: A Review, International Journal of Engineering, Science, and Technology Vol 2 (6) 2010.

2. Schneier, B. (1996), Applied Cryptography $2^{\text {nd }}$ Edition, Wiley \& Sons.

3. Hongmei, T., Liying, H., Yu, H., Xia, W., (2010), An Improved Compound Image Encryption Scheme, Proceeding of 2010 International Conference on Computer and Communication Technologies in Agriculture Engineering.

4. Wei-bin, C., Xin, Z. (2009): Image Encryption Algorithm Based on Henon Chaotic System, Proceeding of International Conference on Image Analysis and Signal Processing (IASP 2009).

5. Struss, K. (2009), A Chaotic Image Encryption, Mathematics Senior Seminar, 4901, University of Minnesota, Morris.

6. Yu, X., Zhang, J., Ren, H., Xu, G., dan Luo, X. (2006), Chaotic Scrambling Algorithm Based on S-DES, Journal of Physics: Conference Series 48, 349-353.

7. Xiang, T, Wong, K., dan Liao, X. (2007), Selective Image Encryption Using a spatiotemporal Chaotic System, Chaos Volume 17. 